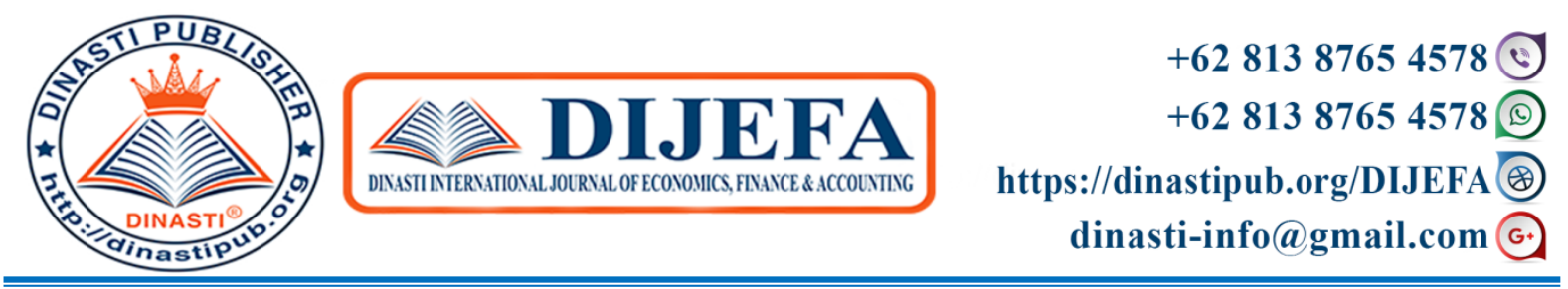

\title{
OVERVIEW OF INCOME TAX ON MORE VAT DIFFERENCES IN RETAIL USED MOTORCYCLE RETAIL
}

\author{
Waidatin Nur Azizah $^{1}$, Suparna Wijaya ${ }^{2}$ \\ ${ }^{1,2)}$ Politeknik Keuangan Negara STAN
}

\begin{tabular}{|l|}
\hline ARTICLE INFORMATION \\
Received: Date Month Year \\
Revised: Date Month Year \\
Issued: Date Month Year \\
(filled in by Editor) \\
Corresponding author: first author \\
E-mail: \\
wiaidatinnura@gmail.com
\end{tabular}

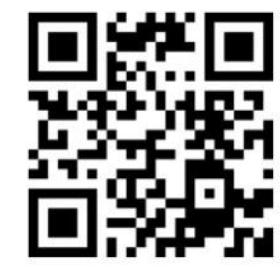

DOI: $10.38035 / D I J E F A$

\begin{abstract}
The delivery of sale secondhand motorized retail of which is subject to a value-added tax of the output of $10 \%$ of the business circulation. According to regulations, Taxable Entrepreneurs may only credit input taxes of $90 \%$ of the output VAT. Therefore, VAT paid to the state is only $1 \%$ of business circulation, so there is a difference of more than $9 \%$ of business circulation. According Law Number 36 the Year 2008, this excess is income so that it can be subject to income tax. However, no regulation confirms this. So this research was conducted. The purpose of this study was to determine aspects of income tax on the excess of value-added tax on the sale or delivery of used motor vehicles in retail. The method used in this research is descriptive qualitative. The results of this study are the difference in valueadded tax on the delivery of used motor vehicles is income.
\end{abstract}

Keywords: VAT Over Difference, Used Motor Vehicles, Input Taxes, Output Taxes

\section{INTRODUCTION}

Motorized vehicles are one of the transportation tools used by many people. Besides being effective and efficient, motorized vehicles are easier to use than conventional vehicles. Because it is used for mobility in everyday life, motorized vehicles are one of the human needs. This can be shown from the development of the number of motorized vehicles from 1949 to 2017 which has a positive trend (Statistics Indonesia, 2017).

Over time, motor vehicles as a means of transportation have developed, both in terms of quality and quantity. The existence of these developments caused the price of new motor vehicle sales to increase from year to year. An example is a motorized vehicle with the Honda Vario 150 brand. Reporting from the autos.id page, the price of a Honda Vario 150 motorbike in December 2017 was Rp21,175,000. Then from the astra-honda.com page, the price of a Honda Vario 150 motorbike was Rp23,834,000 in December 2019. This proves 
that from year to year there is an increase in the selling price of new condition motor vehicles.

Motorized vehicles are the transportation needs of various groups of people. Meanwhile, the needs of the Indonesian people are not only transportation but also more basic needs. According to Esmara H (1986) in Ahmad Soleh (2014) stated, "The components of primary basic needs for the Indonesian people include food, clothing, housing, education, and health". No wonder the society as human beings who think rationally seek more things to meet basic needs than other needs. However, there are still Indonesian people who have not been able to meet basic needs. Economy.kompas.com states that in 2018 there are still 19.4 million Indonesians who cannot meet their daily food needs. From this, it can be concluded that the Indonesian people will tend to put aside other needs before basic needs are met and tend to look for alternatives to be able to meet other needs besides basic needs, one of which is transportation needs. In this regard, buying a used motor vehicle is one of the choices of the people of Indonesia to meet transportation needs. Used motor vehicles can be obtained at much cheaper prices than new condition motor vehicles and are still feasible.

The Central Statistics Agency (2017) released data in 2017, total car sales were 15.49 million and each year showed a growth of $6.24 \%$ annually. As for used cars based on research results from IPSOS, a global research institute explained that in 2016 used car sales reached $60 \%$ of total vehicle sales. This shows how dominantly used car sales are. The following is a comparison of used motor vehicle sales.

\section{Figure I. Comparison of Sales of New Cars and Used Cars in 2016}

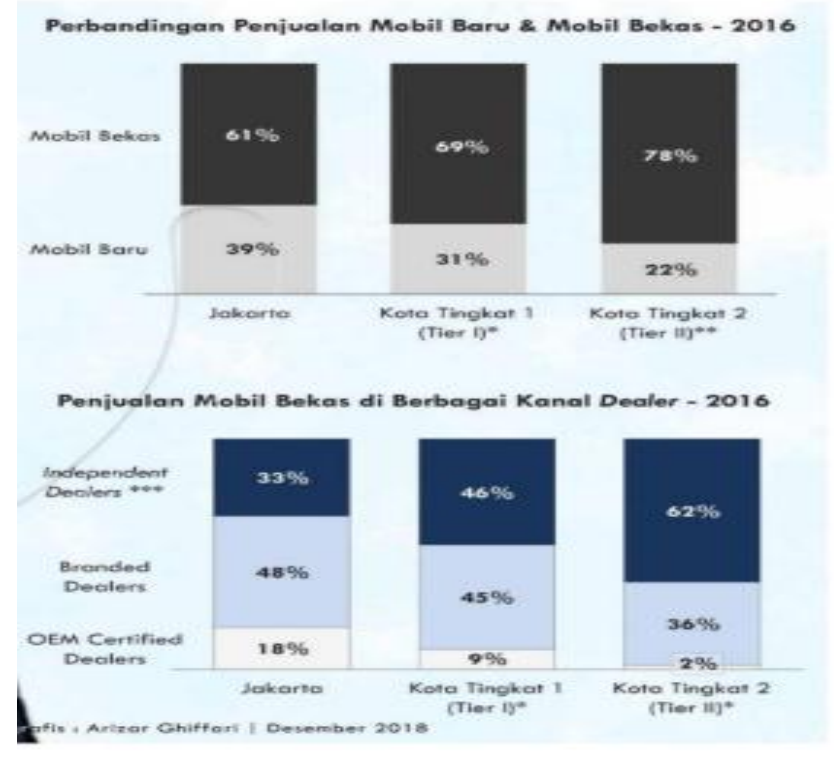

Source: IPSOS

In connection with the sale and purchase of used motor vehicles, this business is a particular business activity whose delivery is subject to value-added tax (VAT). This is regulated in Regulation of the Minister of Finance Number 79 / PMK.03 / 2010 concerning Guidelines for Calculation of Credit Tax Input for Taxable Entrepreneurs Conducting Certain Business Activities. The regulation explained that in the case of the delivery of motorized 
vehicles to consumers, the entrepreneur, in this case, the Taxable Entrepreneur collects an output VAT of $10 \%$ of the circulation of funds. Then, the Taxable Entrepreneur can credit the input tax (PM) of $90 \%$ of the output tax (PK). With the tax calculation mechanism that must be deposited to the state (the output tax mechanism is reduced by an input tax that can be credited), Taxable Entrepreneurs deposit VAT on the delivery of used motor vehicles retail to the state treasury of $1 \%$ of the business circulation. $(1 \%=(10 \% \mathrm{x}$ business circulation $)$ ( $90 \%$ x $10 \%$ x business circulation))

Taxable Entrepreneurs collect $10 \%$ VAT on consumer output and only deposit into the state treasury $1 \%$ of business circulation. Therefore, there is still a difference of more than $9 \%$ of the business circulation of the output tax that has been levied by the Taxable Entrepreneur during the surrender of used motor vehicles. According to the concept of income in Law Number 36 of 2008 concerning Income Taxes (hereinafter referred to as the Income Tax Law), which is the additional economic capability received or obtained by taxpayers, the $9 \%$ difference from the business circulation is the object of income tax. However, there are no regulations that regulate more explicitly the tax treatment of the difference in the imposition of VAT on the delivery of used motor vehicles in retail.

Therefore, this study will discuss income tax on the excess value-added tax (VAT) on the delivery of used motor vehicles in retail. The scope of this research relates to the aspect of value-added tax (VAT) on the surrender of used motor vehicles and the income tax aspect of the excess VAT on the surrender of used motor vehicles.

\section{LITERATURE REVIEW \\ 1. Definition of Tax}

Victor Thuronyi (2003) states that tax can be defined as a compulsory payment to the government or country without direct reciprocity and is used to finance state expenditures intended to serve the public. Besides, the definition of a tax, in general, is also conveyed by Ferdinand Kirchhof (1991) in Victor Thuronyi (2003), "Monetary contributions are imposed unilaterally based on public law that functions to increase revenue and are paid to public authorities". Based on the explanation above, there are characteristics inherent in the tax definition, as follows.

- Tax is one of the obligations that must be fulfilled by the community.

- Tax collection is based on the provisions of the applicable laws and regulations,

- taxpayers do not get reciprocity or counter-achievement directly,

- $\quad$ tax is used to finance state expenditures intended to serve the public.

There are several tax divisions in tax law based on the characteristics of each type of tax (Brotodihardjo \& Santoso, 1995). One division of taxes is a direct tax and indirect tax. Beltrame \& Mehl (1997) in Victor Thuronyi (2003) said that direct taxes are imposed on individuals or property, while indirect taxes are imposed on manufacturing, sales, consumption, and the like and the payments are made indirectly by consumers. In the World Trade Organization Agreement, it is explained that direct taxation is the taxation of salaries, profits, interest, rent, royalties, and other income in any form, as well as taxation of property ownership. While indirect taxes are imposed on sales, excise, transfers, value-added, 
franchises, seals, transfers, inventory and equipment taxes, border taxes, and other taxes besides direct taxes and import fees (Thuronyi, 2003).

\section{Definition of Income}

Three general concepts explain the definition of income, namely the concept of addition (accretion concept), the concept of sources (source concept), and the trust concept. The accretion concept is applied in the United States. This concept explains that each additional wealth is called income. Meanwhile, income according to source concept is something that comes from sources of income. Meanwhile, according to the trust concept is the concept of income that is commonly found in commonwealth countries (commonwealth countries). Whatever income concept is applied, income must be realized to be taxed (Thuronyi, 2003).

\section{Income Tax Income}

tax is a progressive tax, especially an individual income tax which is calculated annually and takes into account all taxable income (Prastowo, Bahagijo, \& Nikmah, __). The amount of income tax to be paid can be determined from the tax rate times net income. Net income comes from all income less a predetermined reduction, for example, non-taxable income (PTKP) (Thuronyi, 2003).

\section{Value Added Tax Value}

added tax (VAT) is a transaction tax that is collected at all stages of production and distribution. This tax is levied on goods and services transactions. Transactions subject to tax are the supply of goods and services specified in the regulations. The intended goods are tangible goods, except land and money. While services that are subject to VAT cannot be determined with certainty and comprehensively (Thuronyi, 2003).

The mechanism used to determine domestic consumption VAT is the invoice-credit mechanism. Taxpayers who have a tax invoice for goods or service acquisition transactions can credit with the tax paid to the entrepreneur providing the goods or services. This credit only applies to goods or services directly related to businesses that are taxed (Thuronyi, 2003).

\section{Previous Research}

Sophy Widya Lastari and Icha Fajriana (2018) explained that the imposition of VAT on the delivery of used cars was carried out by the entrepreneur himself. Besides, the contribution of VAT to the delivery of used cars at KPP Pratama Palembang Ilir Timur in 2014-2016 was lacking due to a lack of understanding and knowledge of VAT regulations in this business.

M. Enteguh Syach Ginting and Suparna Wijaya (2018) explained that there were differences in the collection of VAT on retail sales of used motor vehicles based on KMK Number 251 / KMK.03 / 2002 and PMK Number 79 / PMK.03 / 2010. According to KMK 567 / KMK.03 / 2002, the purchase price borne by used motor vehicle consumers is smaller than when PMK 79 / PMK.03 / 2010 was applied. Furthermore, PKP sellers of used motor 
vehicles also benefit more from this new scheme, because they get a difference of more than $9 \%$ of the total VAT collected from buyers by $10 \%$ or $90 \%$ of the total VAT collected.

\section{RESEARCH METHODS}

In working on this journal, the writer uses qualitative methods. Morse in Cresswell (2014) states that qualitative methods are needed to explain things in-depth that cannot be stated in quantitative measures. Besides, qualitative methods are used because new research topics, subjects are not stated in the sample, and existing theories cannot be applied to the sample. Source of data used in this study are primary data and secondary data. Primary data come from interviews, while secondary data are sourced from books, journals, regulations, and other literature. Interviewees included academics in the fields of accounting and taxation and researchers in the Fiscal Policy Office.

\section{FINDINGS AND DISCUSSION}

\section{The Retail Value Added Aspect of Handover of Used Motorized Retail}

Vehicles Motorized vehicles are taxable goods. Act Number 42 of 2009 concerning the Third Amendment to Act Number 8 of 1983 concerning Value Added Tax of Goods and Services and Sales Tax on Luxury Goods (Article 4A of the Law VAT) paragraph 2 states that four types of goods are not taxed value-added (VAT). The four types of goods not subject to VAT are as follows:

a. mining or drilling goods are taken directly from the source;

b. staple goods that are needed by many people;

c. food and beverages served in hotels, restaurants, restaurants, food stalls, and the like, including food and beverages whether consumed on-site or not, including food and beverages delivered by Aboga suits or catering businesses, and

d. money, gold bars, and securities.

The substance of article 4A paragraph 2 of the VAT Law is a negative list which means the types of goods not mentioned in the article are taxable goods. Therefore, motorized vehicles are types of goods subject to VAT (ABC, 2020).

In connection with the business of buying and selling used motor vehicles in retail, the delivery of motorized vehicles is subject to value-added tax (VAT). This is regulated in article 4 of the VAT Law, namely that the value-added tax is imposed on the surrender of taxable goods (BKP) within the customs area carried out by the businessman. Besides, the business of buying and selling used motor vehicles is a certain business activity. This is regulated in Minister of Finance Regulation Number 79 / PMK.03 / 2010 article 2. Referred to ascertain business activities because, in the business process, entrepreneurs buying and selling used motor vehicles obtain goods (used motor vehicles) from consumers who are mostly private individuals and not PKP. Thus, the individual cannot issue a tax invoice for the surrender of motorized vehicles so that entrepreneurs (PKP) buying and selling used motor vehicles cannot credit the input tax on the acquisition of the merchandise. Besides, in running this business, entrepreneurs do not buy other capital goods so that no input tax can be 
credited. If using a public mechanism (output tax minus input tax), entrepreneurs buying and selling used motor vehicles will object because they are required to pay an output tax in the amount of surrender carried out without crediting the input tax (Setiawan HB, 2020).

Besides, there are four components of risk faced by PFM and are considered by the state in establishing a policy for crediting the input tax of $90 \%$ of the output tax. First, related to acquisition costs. Often PKP has encountered several shortcomings when obtaining used motor vehicles. This deficiency requires PKP to pay for repairing damage by replacing some spare parts and regularly cleaning the used motor vehicle inventory to make it look attractive. Second, related to maintenance until it is sold, namely PKP must clean the vehicle, change oil, buy fuel to heat the vehicle, and maybe replace spare parts that are no longer suitable for use. Third, motor vehicle tax. The longer it has not been sold, the motor vehicle tax will be borne by the seller, both from the tax base and administrative sanctions, as well as the risk of pulling off a file (vehicle mutation) if the buyer is from out of town. Fourth, the risk of falling market prices, the market price of used motor vehicles decreases every year even though the vehicle is not in use and is always being treated as long as it has not been sold (ABC, 2020).

Therefore, to maintain business continuity, the government through the Ministry of Finance regulates an input tax that can be credited by entrepreneurs engaged in the sale and purchase or handover of used motor vehicles, in this case, the entrepreneur has been confirmed as a taxable entrepreneur (PKP) (Setiawan HB, 2020). In the Regulation of the Minister of Finance No. 79 / PMK.03 / 2010 it is regulated that the PKP submitting used motor vehicles retail can credit an input tax of $90 \%$ of the output tax. And the output tax in question is a tax on the surrender of used motor vehicles from PKP to final consumers of $10 \%$ of business circulation. With the mechanism for calculating VAT (output tax minus input tax), PKP only deposits VAT on the delivery of used motor vehicles to the state treasury at $1 \%$ of the business circulation. The mathematical calculation is $1 \%=(10 \% \mathrm{x}$ business circulation) - (90\% x $10 \%$ x business circulation).

\section{The aspect of Income Tax on the Difference in Over VAT on Submission of Retail Used Motorized Vehicles}

The handover of used motor vehicles by taxable entrepreneurs to consumers is subject to VAT of $10 \%$ of gross circulation. This tax is called output tax because of surrender. Based on PMK Number 79 / PMK.03 / 2010, for the business of handing overused motor vehicles, the input tax that can be credited is calculated using the guideline for calculating an input tax credit of $90 \%$ of the output tax. With the mechanism for calculating VAT payable (output tax minus input tax), VAT that must be deposited to the state treasury is $1 \%$ of business circulation $(1 \%=(10 \% \times$ business circulation $)-(90 \% \times 10 \% \times$ business circulation $)$. Because only $1 \%$ is deposited to the state treasury, there is a difference of more VAT on the delivery of used motor vehicles for retail at $9 \%$ of business circulation (ABC, 2020).

According to Hadi Setiawan (2020), the difference is more VAT collection on the delivery of vehicles used motorcycles that are not deposited into the state treasury will be income for PKP. Hadi Setiawan (2020) also said the same thing that the difference of more than $9 \%$ VAT from the circulation of businesses in the delivery of used motor vehicles could 
be income for PKP. this excess is in the form of cash collected from consumers for the delivery of BKP (used motor vehicles) and the state (government) only gives instructions to deposit into the state treasury only as gian and does not further regulate how the tax treatment for this excess. Therefore, this excess can be subject to income tax.

Table I. Difference in Treatment of VAT Over Submission of Used Motor Vehicles

\begin{tabular}{|c|c|c|}
\hline Mr. ABC & $\begin{array}{l}\text { Fiscus, academics, and } \\
\text { practitioners in the field of } \\
\text { taxation }\end{array}$ & $\begin{array}{l}\text { It becomes income and may be subject to } \\
\text { income tax because VAT collected from } \\
\text { consumers is not entirely deposited into } \\
\text { the state treasury so that there is a residue } \\
\text { that is still brought by the PKP. This } \\
\text { refers to article } 4 \text { of the Income Tax Law, } \\
\text { any additional economic capacity } \\
\text { obtained by taxpayers from Indonesia in } \\
\text { any form. }\end{array}$ \\
\hline Haris Budi Setiawan & $\begin{array}{l}\text { Fiscus, academics, and } \\
\text { practitioners in the field of } \\
\text { taxation }\end{array}$ & $\begin{array}{l}\text { May be income based on article } 4 \\
\text { paragraph } 1 \text { letter p of the Income Tax } \\
\text { Law, which is the addition of net assets } \\
\text { derived from income that has not been } \\
\text { taxed. }\end{array}$ \\
\hline Hadi Setiawan & $\begin{array}{c}\text { Researcher at the Fiscal } \\
\text { Policy Agency }\end{array}$ & $\begin{array}{l}\text { It can become income based on article } 4 \\
\text { of the Income Tax Law, which is an } \\
\text { additional economic capability in } \\
\text { whatever form the taxpayer receives } \\
\text { from Indonesia. }\end{array}$ \\
\hline
\end{tabular}

The difference in the collection of VAT on the surrender of used motor vehicles is due to the policy of determining the input tax that can be credited by PKP. The general rule explains that the input tax that is related to the business and has a complete tax invoice can be credited with the output tax. This input tax arises when the taxpayer purchases or obtains BKP / BKPTB / JKP related to the business. However, this does not apply to certain business activities such as the delivery of used motor vehicles at retail. As explained previously, in PMK Number 79 / PMK.03 / 2010 it has been regulated that PM that can be credited by PKP who hand overused motor vehicle retail is $90 \%$ of the output tax. Because of these provisions, PKP is no longer allowed to credit input taxes on all BKP / BKPTB / JKP acquisition or import. So, no matter how much the PKP input tax from the BKP / JKP acquisition, the calculation of the input tax remains from the specific guidelines. So, as long as the business is running, there will still be an input tax, whether in reality there is no BKP / JKP acquisition or any acquisition. Thus, the difference between the collection of VAT will remain as long as there are no changes to this regulation (Setiawan HB, 2020).

On the one hand, PKP cannot credit the PM for the acquisition or import of BKP / BKPTB / JKP related to its business. But on the other hand, PKP who hand overused motor vehicles has the right to credit the PM at $90 \%$ of the PK. And the output tax (PK) collected by the PKP must be $10 \%$ of the sale value or circulation of the business so that there will always be a difference of more than $9 \%$ of the business circulation. 
Furthermore, according to (ABC, 2020) through the debt relief approach, the difference over VAT on the surrender of used motor vehicles can be proven as income for PKP and subject to income tax (PPh). What is meant by debt relief is the decision to free debt or not collect debtors' debts by creditors, while the process of debt relief is called debt writeoffs (A, 2020), Debt write-off is the process of deleting debtor debt records so that they are no longer recognized in the financial statements. Debt write-offs usually occur for two reasons, first because of a decision from the authorities (for example, a bankruptcy case) and second because it is voluntary (usually an affiliate relationship).

In accounting, it is not explicitly explained about the write off of debt, but the write off of accounts receivable in PSAK 55 which was updated with PSAK 71 concerning financial instruments. Debt and receivables are financial instruments and occur on two parties, namely the debtor and creditor. Both are reciprocal relationships. The existence of a debt write-off certainly begins with the write-off of credit by a creditor. However, for certain cases, debt write-offs can occur without the beginning of writing off receivables by creditors. This happens because creditors do not record the right to collect receivables from debtors (A, 2020).

Table II. Relationship of Debt and Debt Eliminationoffs

\begin{tabular}{|c|l|l|}
\hline Relief of Dinarjito & $\begin{array}{c}\text { Academics in the field of } \\
\text { accounting There }\end{array}$ & $\begin{array}{l}\text { is no term for debt relief, but rather debt } \\
\text { write-. Debt write-offs are regulated in PSAK } \\
55 \text { (now PSAK 71). }\end{array}$ \\
\hline Zef A & Academics in accounting & $\begin{array}{l}\text { Debt exemption is not known in accounting. } \\
\text { However, there is a relationship between debt } \\
\text { relief and debt relief. Debt relief is a decision } \\
\text { to free debt or not collect debtors' debts. } \\
\text { While debt write-off is the process of writing } \\
\text { off debtor debt balances in the financial } \\
\text { statements so that they are no longer } \\
\text { recognized. }\end{array}$ \\
\hline
\end{tabular}

In this case, the debtor or debtor is the taxpayer (PKP) and the government as the creditor (the debtor). Meanwhile, the debt in question is tax debt, namely the debt of output VAT. Each submission is made, PKP must collect output VAT and record it in the bookkeeping as output VAT debt. After that, the PKP is obliged to deposit the debt to the state. The following is the recording scheme.

Recording when submitting (selling)

Cash

XXX

Selling

XXX

Debt output VAT

$\mathrm{XXX}$

Recording when depositing VAT debt output to the state treasury

Debt output VAT

Cash

XXX

In accounting, these debts must all be deposited because they are third party debt from economic transactions (Dinarjito, 2020 ). On the other hand, the state (government) regulates 
that the PPN debt output paid by PKP to the state is not as much as it levies from third parties for the delivery of goods, but only a percentage of the gross circulation of economic transactions. This causes a difference in the collection of VAT on the delivery of goods in economic transactions. As a result, there is an outstanding VAT debt in the PKP bookkeeping. And in this case, the state as a creditor does not record in accounting the receivables that can still be collected from the debtor on the difference between the collection of output VAT and deposits to the state treasury.

In this connection, the difference between the collection of VAT or the balance of VAT debt output in the debtor's bookkeeping (PKP) can be written off. In the conceptual framework of financial statements, it is stated that revenue is an increase in equity characterized by an increase in assets or a decrease in debt that does not originate from direct transactions with the owner (Dinarjito, 2020). In line with this, debt write-offs will be income for debtors. In terms of taxation, income is also defined as income. Therefore, to write off the debt balance of output VAT on the surrender of used motor vehicles, the PKP (the debtor) records the benefits of the write off of output VAT debt in the credit department. The recording is carried out in conjunction with the recording when depositing the output VAT debt to the state treasury. The following is the recording scheme.

Output VAT debt

Cash

Advantage output VAT debt relief
XXX

$\mathrm{XXX}$

$\mathrm{XXX}$

or

debt VAT output

XXX

Other income

XXX

Gain output VAT debt relief or other revenue accounts will be reported in the financial statements of income, exactly in the other income. Referring to the concept of income article 4 of the Income Tax Law, which is the object of income tax is any additional economic ability obtained by taxpayers originating from Indonesia or outside Indonesia, which can be used for consumption or to increase the wealth of the taxpayer concerned, by name and whatever. Therefore, the written-off VAT debt balance can be subject to income tax.

Table III. Accounting treatment for the difference over VAT collection in the delivery of used motor vehicles

\begin{tabular}{|c|l|l|}
\hline Agung Dinarjito & Academics in accounting & $\begin{array}{l}\text { For the difference in VAT collection } \\
\text { (account: VAT debt), a VAT debt account } \\
\text { (D) is recorded against other income accounts } \\
\text { (K). This other income will be included in } \\
\text { other income accounts' financial statements. }\end{array}$ \\
\hline Zef A & Academics in accounting & $\begin{array}{l}\text { The excess of this VAT collection can be } \\
\text { recorded when paying or depositing VAT to } \\
\text { the state treasury by recognizing the benefits } \\
\text { of writing off VAT debt. The records are the } \\
\text { VAT debt account for the collected VAT (D) } \\
\text { on the cash account for depositing VAT debt }\end{array}$ \\
\hline
\end{tabular}




\begin{tabular}{|l|l|}
\hline \multirow{7}{|l|}{} & $\begin{array}{l}\text { to the state treasury }(\mathrm{K}) \text { and the benefits of } \\
\text { writing off VAT debt on the excess collection } \\
\text { fee }(\mathrm{K}) \text {. The benefits of writing off VAT debt } \\
\text { will be included in other income items in the } \\
\text { financial statements. }\end{array}$ \\
\hline
\end{tabular}

\section{Illustration}

It is assumed that Mr. A is a Taxable Entrepreneur in the business of buying or selling used motor vehicles. On January 21, 2020, Mr. A made an economic transaction with Mr. Z. Mr. Z bought a used motor vehicle from Mr. A for Rp 100,000,000 excluding VAT. Then, Mr. A will make an accounting recording of the submission as follows.

Cash

$110,000,000$
Sales
Output VAT Debt
$100,000,000$
$10,000,000$
(10\% x Rp 100,000,000)

Then, Mr. A deposits the VAT owed to the state treasury no later than the end of February. The following is the VAT calculation.

\begin{tabular}{|l|r|}
\hline $\begin{array}{l}\text { Output VAT (Output Tax) } \\
\text { This output VAT is the tax paid by Mr. Z when handing over a } \\
\text { used motor vehicle from Mr. A. }\end{array}$ & $10,000,000$ \\
\hline $\begin{array}{l}\text { input VAT (Input Tax) based on the calculation guidelines for } \\
\text { crediting credit input }\end{array}$ & $9,000,000$ \\
$90 \%$ output tax = 90\% x Rp10.000,000 & $1,000,000$ \\
\hline $\begin{array}{l}\text { VAT to be deposited to the state by Mr. A as the PKP } \\
\text { submitting used motor vehicles } \\
\text { The mechanism of calculating the output tax minus input tax }\end{array}$ \\
\hline
\end{tabular}

On depositing the VAT accrued to the state treasury, Mr. A records in accounting as follows.

Output VAT Debt $\quad 1,000,000$

Cash

$1,000,000$

In accounting, the recording should be done is to continue debiting the output VAT debt of Rp10,000,000 and crediting cash in the amount of Rp1,000,000 and the benefit of writing off output VAT debt of Rp9,000,000. Or debit an output VAT debt of IDR 9,000,000 and credit another income of IDR 9,000,000.

Output VAT Debt

Cash

Profit from VAT Debt Output

Output VAT Debt

$(10,000,000-1,000,000)$

Other income

$$
10,000,000
$$

$9,000,000$

Or

$9,000,000$

$9,000,000$ 


\section{CONCLUSION AND SUGESTION}

Retail sales or handover of used motor vehicles subject to value-added tax (VAT). The tax levied at $10 \%$ of the selling price or business circulation, is called the output tax (output VAT). In calculating the VAT owed, the taxable entrepreneur (PKP) of used motor vehicle sales can credit the input tax according to the credit guidelines, which is $90 \%$ of the output tax. Taxable entrepreneurs who apply this special guideline cannot credit other input taxes for obtaining BKP / JKP and cannot finance them in calculating income tax. The existence of this credit guideline results in a difference in the collection of VAT. Based on taxation and accounting regulations, this excess is defined as income earned by employers so that it can be subject to income tax. However, the tax treatment of the excess of the collection of VAT on the surrender of used motor vehicles has not been regulated in more specific regulations. This causes legal uncertainty. So, it is needed a detailed regulation about taxation of VAT differences of secondhand motorized retail in order to have a fix regulation.

\section{REFERENCE}

A, Z. (2020, 01 20). Perlakuan Akuntansi terhadap Selisih Lebih Pemungutan PPN Penyerahan Kendaraan Bermotor Bekas secara Eceran. (WN Azizah, Interviewer)

ABC. (2020, 01 22). Perlakuan Perpajakan Penyerahan Kendaraan Bermotor Bekas secara Eceran. (WN Azizah, Interviewer)

Badan Pusat Statistik. (nd). Retrieved 02 15, 2020, from bps.go.id

Brotodihardjo, \& Santoso. (1995). Pengantar Ilmu Hukum Pajak. Bandung: PT Eresco.

Creswell, J. (2014). Research Design: Qualitative, Quantitative and Mixed Methods Approaches. Thousands of Oaks: Sage Publications.

Dinarjito, A. (2020, 01 22). Perlakuan Akuntansi terhadap Selisih Lebih Pemungutan PPN Penyerahan Kendaraan Bermotor Bekas secara Eceran. (WN Azizah, Interviewer)

Ginting, M., \& Wijaya, S. (2018). Pajak Pertambahan Nilai Terhadap Penyerahan Kendaraan Bermotor Bekas secara Eceran: Siapa yang Paling Diuntungkan? Seminar Nasional I Universitas Pamulang .

Ipsos Business Consulting. (2016, 09). Retrieved 02 15, 2020, from ipsos.com: https://www.ipsos.com/sites/default/files/2016-09/Indonesia-growing-automotiveaftermarket-landscape.pdf

Kompas. (2018, 04 03). kompas.com. Retrieved 01 07, 2020, from ekonomi.kompas.com: 2. https://ekonomi.kompas.com/read/2018/04/03/140000126/19-4-juta-orang-indonesiatidak-dapat-memenuhi-kebutuhan-pangan?page=all

Lastari, SW, \& Fajriana, I. (2018). Analisis Pengenaan dan Kontribusi Pajak Pertambahan Nilai atas Penyerahan Mobil Bekas (Studi Kasus pada Kantor Pelayanan Pajak Pratama Palembang Ilir Timur).

Prastowo, Y., Bahagijo, S., \& Nikmah, SK (_). Cross-Country Research on Tax Policy and Inequality: Comparative Study of Indonesia, South Africa, and Brazil. _.: International NGO Forum on Indonesian Development. 
Setiawan, H. (2020, 01 16). Perlakuan Perpajakan terhadap Selisih Lebih PPN pada Penyerahan Kendaraan Bermotor Bekas secara Eceran. (WN Azizah, Interviewer)

Setiawan, HB (2020, 01 23). Perlakuan Perpajakan atas Penyerahan Kendaraan Bermotor Bekas secara Eceran. (WN Azizah, Interviewer)

Soleh, A. (2014). Pertumbuhan Ekonomi dan Kemiskinan di Indonesia. Ekombis Review 2, no. 2 .

Thuronyi, V. (2003). Comparative Tax Law. Hague: Martinus Nijhoff Publishers. 